\title{
P69 アルミニウム中空押出し形材の軸圧潰挙動と緩衝特性に及ぼす孔の影響
}

Influence of a hole on axial crush behaviors and buffer characteristics of aluminum hollow extrusions

○大岩 憲史（芝浦工大(院)）正 岡本紀明（芝浦工大）酒井 拓真（㑣シマノ）

Kenji OOIWA, Shibaura Institute of Technology, 3-7-5, Toyosu Koutou-ku, Tokyo

Noriaki OKAMOTO, Shibaura Institute of Technology, 3-7-5, Toyosu Koutou-ku, Tokyo

Takuma SAKAI,SHIMANO,3-77,Oimatuchou Sakai-ku Sakai-si Oosaka

1. 緒言 鉄道車両は大人数輸送, 高速運転の特徵から質量 が巨大で衝突エネルギは自動車の1000倍程大きく，クラッシ ヤブルゾーンも限られていることから, 乗員や乗客の安全を 確保するための耐衝突構造を考えた場合, 相応の工夫が必要 である。その機能を実現する一構造形態として，今までの研 究からアルミニウム中空押出形材（以下，中空形材）で構成 した箱型構造が有効である事が判明している ${ }^{(1)}$. そして，衝 撃吸収構造として車両端下部に設置する際に，鉄道車両下部 には連結器・各種タンクなどが密に配置されており, それら を繋ぐ電気配管・空気配管を通すための孔が必要になる．本 研究では要素実験で, 孔が中空形材の軸圧潰挙動に与える影 響を解明し，緩衝特性に対する孔の最適化を検討する.

\section{2. 圧潰実験の供試体と方法}

（1）実験供試体供試体に使用される中空形材の材料とし て，エネルギ吸収効率の良い焼鈍材 A6N01-0 を使用した(2). 供試体形状を図 1 , 供試体写真を図 2 , 断面寸法をピッチ 1 とした比で表 1 に示す. 孔は供試体の中心に貫通させ，孔な しを $\mathrm{H}-0$ として孔径 $d$ を $\mathrm{H}-d$ で示す. Model-1 は H-0, H-20, $\mathrm{H}-30, \mathrm{H}-40, \mathrm{H}-50, \mathrm{H}-70$. Model-2 は H-0, H-30, H-40, H-50, H-60, H-70 でMode1-2 はピッチが Model-1 より 1.3 倍大きい. 供試体の長さは押出方向に $200 \mathrm{~mm}$, ピッチ数は 3 とする.

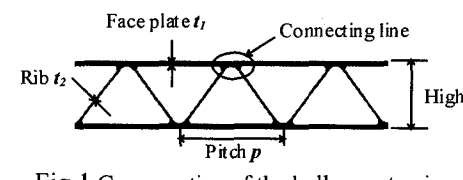

Fig. 1 Cross section of the hollow extrusion

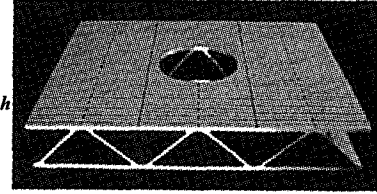

Fig.2 Model-1_H-40
Table 1 Test piece size

\begin{tabular}{|c|c|c|c|c|c|}
\hline model & $p / p$ & $h / p$ & $t_{l} / p$ & $t_{2} / p$ & $d / p$ \\
\hline \hline Model-1 & 1 & 0.53 & 0.038 & 0.026 & $0,0.30,0.45,0.60,0.76,1.06$ \\
\hline Model-2 & 1 & 0.47 & 0.033 & 0.020 & $0,0.35,0.47,0.59,0.71,0.82$ \\
\hline
\end{tabular}

（2）実験方法実験は壁面座屈モード, 面外変形量を測定す るために実体格子型モアレトポグラフィを用いた。図 3 のよ うに, 1 本のモアレ縞が $1 \mathrm{~mm}$ の面外変形量となるように光学 系を設定した. そして, 試験機に図 4 のガイドと加圧子を用 いた供試体を取り付け軸方向に約 $100 \mathrm{~mm}$ 押込み変位を与えた。

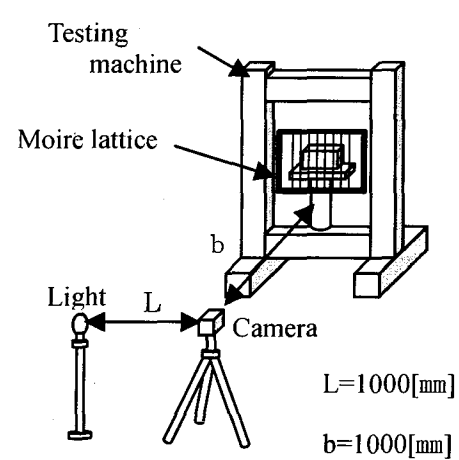

Fig.3 Setup for Moiretopography

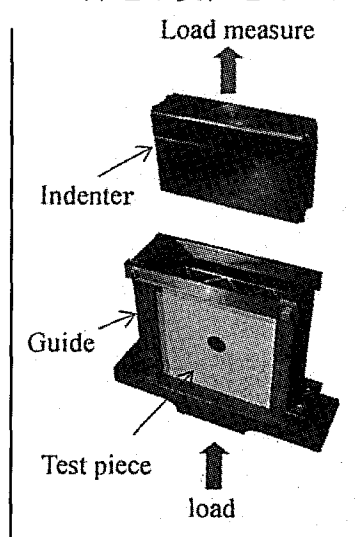

Fig.4 Experimental rig
3. 荷重-変位曲線図 5 に実験より得た Model-1の荷重-変 位曲線を示す. H-0 は第 1 ピーク荷重 (a 点) 後に急激な荷重降 下が起き，その後に荷重が再上昇した (b 点)。そして，再荷
重上昇後は大きな荷重の変動もなくプラトー状態になった. 孔ありの例として $\mathrm{H}^{-} 40$ を見ると, 同様に第 1 ピーク荷重 (a'点) 後は荷重が降下し, その後, 再上昇した ( $b^{\prime}$ 点). しかし, 孔 ありは第 1 ピーク荷重が大幅に抑えられ, 再荷重上昇との差 が少なくなり H-0 と比べ第 1 ピーク荷重から圧潰終了まで平 らな荷重-変位曲線となった. また, 図示していないが Mode1-2 は供試体寸法が大きい分荷重は高いが, 荷重-変位曲線の推移 は孔なしと孔ありともにModel-1 と類似した特徵を示した。

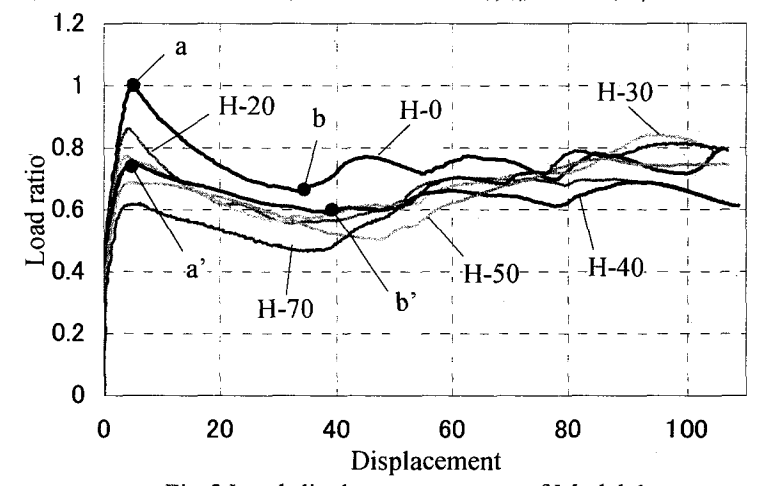

Fig. 5 Load-displacement curves of Model-1

4. 壁面座届の推移図 6 にModel-1の ーク荷重時 (a 点, a'点)における壁面座屈の凹凸を示す. H-0 は主に上段から圧潰が始まるのに対し, H-40 は中段から圧潰 が始まる，そして，面外変形では A-A 面板において H-40 は変 形が少ないことが分かる。これは孔によって面板が途切れて 力が加わらないためである. その分 $\mathrm{B}-\mathrm{B}$ 結節線・ $\mathrm{C}-\mathrm{C}$ 面板で 力を支えるため, B-B 結節線・C-C 面板の凹凸の変形は大きく, 最大振幅は H-0 では $4 \mathrm{~mm}$ だが H-40 では $6 \mathrm{~mm}$ となった。 孔 によって荷重を支える面積が少なくなり，H-0 と比べて孔あり は壁面座屈が発生し易く第 1 ピーク荷重が抑えられた。

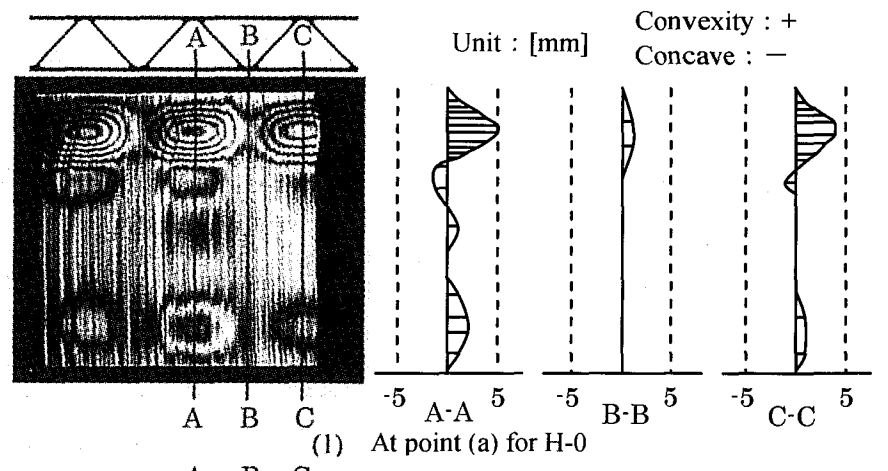

A B C
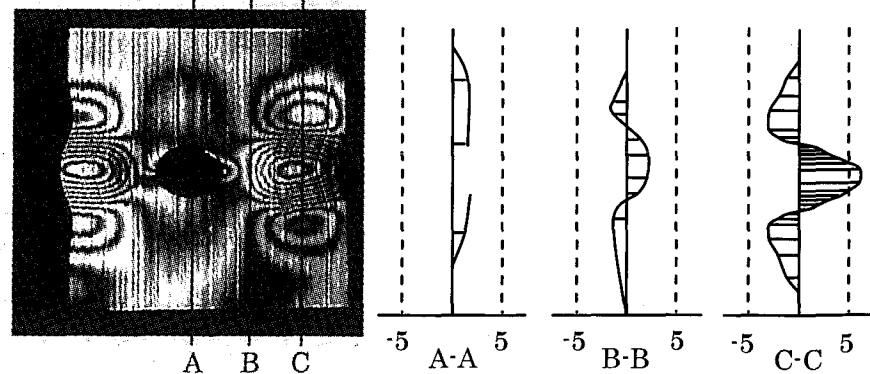

(2) At point (a') for $\mathrm{H}-40$

Fig.6 Wall-deformations for $\mathrm{H}-0$ and $\mathrm{H}-40$ of Model- 1 at first peak load

日本機械学会 (No. 06-4] M\&M2006 材料力学カンファレンス講演論文集( ‘06. 8.4-6, 浜松市) 
次に再荷重上昇時 ( $\mathrm{b}$ 点、 $\mathrm{b}^{\prime}$ 点) の壁面座屈を図 7 に示寸. 第 1 ピーク荷重時の変形モードが成長し, H-0 では凹方向に大 きく変形した．第 1 ピーク荷重後の落ち込みは面板・結節線 の座屈によって起き, 特に B-B 結節線の変形の変化が大きい ことから，荷重を支えるのに大きく影響するのは結節線であ ると考えられる。そして が $\mathrm{H}-40$ より急なのは, $\mathrm{H}-0$ は荷重支持面積が大きい分，座屈 による落ち込みも大きくなるからである.ささらに, 図 7 より H-0 は壁面座屈が上段のみで発生するのに H-40 は全体で壁面 座屈が発生するため変形が進み易く, その分荷重が緩やかに 推移すると考えられる. 図 8 に $\mathrm{H}-40$ の圧潰終了後の供試体を 切断した断面写真を示す. 再荷重上昇後に荷重が大きく落ち 込むことなくプラトー状態となったのは，孔なしと同様に孔 ありの場合でも蛇腹状に壁面座屈が起こり, 図 8 のように面 板・リブが自己接触を起こし, 荷重を保持しながら圧潰が進 むからであると考えられる。

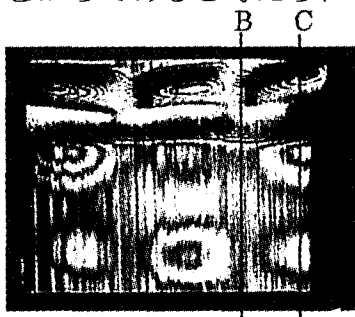

B C

B C

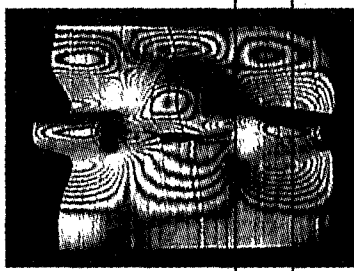

B C

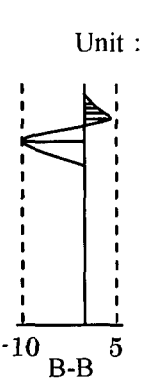

(1) At point (b) for $\mathrm{H}-0$

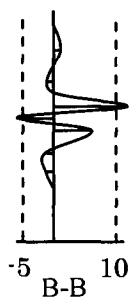

2) At point ( $\left.b^{\prime}\right)$ for $\mathrm{H}-40$

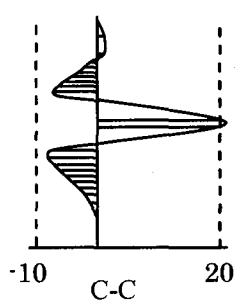

Fig.7 Wall-deformations for $\mathrm{H}-0$ and $\mathrm{H} 40$ of Model-1 at re-load rise
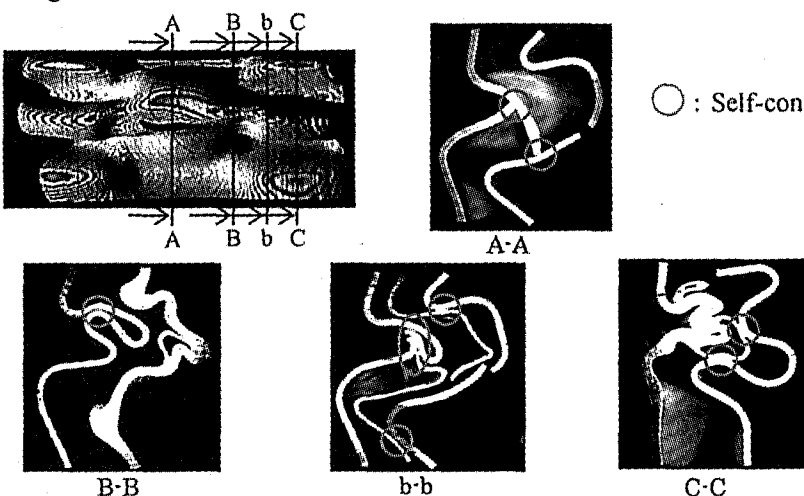

$\mathrm{C} \cdot \mathrm{C}$

Fig. 8 Wall-deformation and cross sections in $\mathrm{H}-40$ of Model-1 after test 5. ピーク荷重と孔径 図 9 にMode1-1 とMode1-2のそれぞ れの孔径に対する断面積と第 1 ピーク荷重の関係を示す.

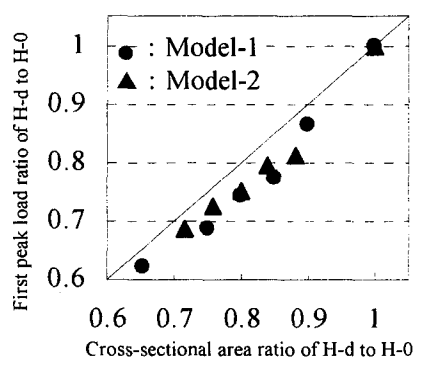

Fig.9 Cross-sectional area vs. peak load
Mode1-1 とModel-2の関係は類 似しており，傾き 1 の線上 より第 1 ピーク荷重比は 0.08 以内のずれで収まり， 第 1 ピーク荷重と断面積之 は比例に近い関係である。 孔径が大きくなるほど第 1 ピーク荷重が落ち込むのは, 孔によって荷重を支える断 面積の減少が一因であると 考えられる.
6. 緩衝特性図 10 にMode1-1 とMode1-2 の孔なし H-0を 1 とした孔径比 $d / p$ に対する緩衝特性を示す．エネルギ吸収 効率 $\eta$ は孔によって上昇した. Model-1 は H-40 で 15\%増, Model-2 はH-70 で 25\%増となった。これは，エネルギ吸収量 Qが孔による落ち込みはあるものの, 孔径では大きく落ち込 むことなく横ばいに推移したのに対し, 最高荷重 $P_{\text {max }}$ は孔に よって減少したためである.しかし, Mode1-1でエネルギ吸収 効率 $\eta$ は山形の推移となることより，孔径が大きくなり過ぎ てもエネルギ吸収効率 $\eta$ は減少することが判明した。特に Mode1-1の孔径比 1 以上の H-70 は, 図 5 より他と比べて第 1 ピ 一ク荷重から再荷重上昇までが大きく減少している. 孔径比 1 以上は図 1 において真ん中の 3 つの結節部を削り, 荷重支 持面積の減少が大きいため, 第 1 ピーク荷重から再荷重上昇 までが下がり過ぎて，エネルギ吸収効率 $\eta$ を下げる結果とな った. 次に Mode1-2 では孔径比 0.82 でも緩衝効率は上昇した. これは Model-1 と断面寸法が異なるため違いが生じる. Mode1-2 は第 1 ピーク荷重が高くて再荷重上昇までの落ち込 みが Mode1-1より大きく,H-0のエネルギ吸収効率 $\eta$ は Mode1-1 が 72\%に対してMode1-2 は 65\%であった。 そして, Mode1-2 の方が第 1 ピーク荷重から再荷重上昇までの荷重の幅が大き い分, 孔径比 0.82 でも第 1 ピーク荷重が下がり過ぎることは なくエネルギ吸収効率 $\eta$ は上昇した. しかし, 孔径比 1 を超え れば Mode1-1 と同様に結節部の減少により，エネルギ吸収効 率 $\eta$ は減少すると考えられる。

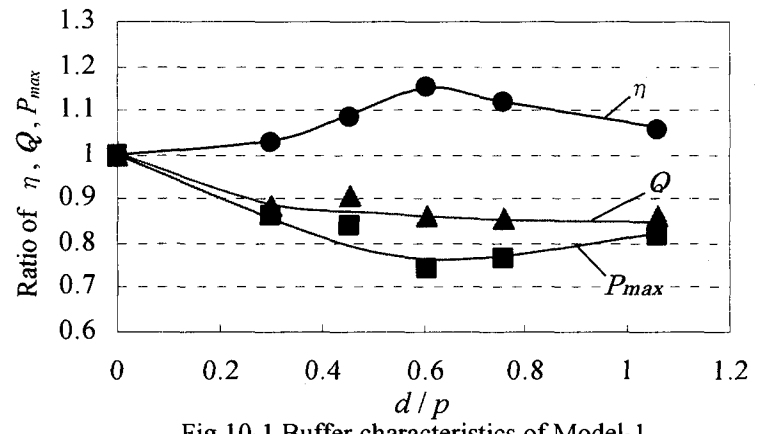

Fig.10-1 Buffer characteristics of Model-1

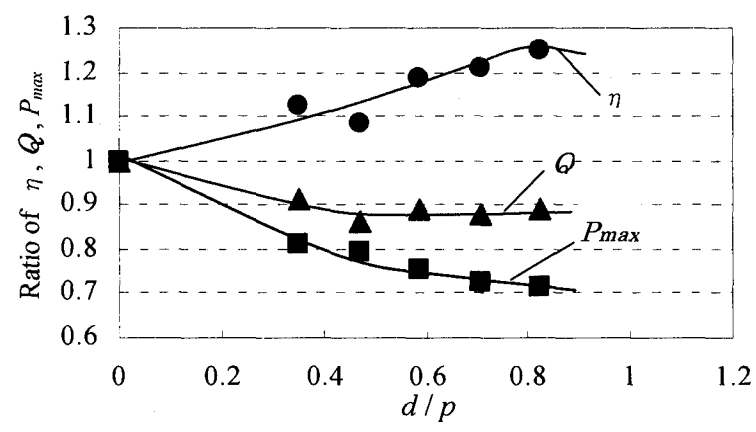

Fig.10-2 Buffer characteristics of Model-2

$$
\begin{array}{ll}
P_{\max }: \text { 最高荷重 } & P_{m}: \text { 平均荷重 } \\
Q: \text { エネルギ吸収量 } & \delta \max : \text { 最終押込み変位 }
\end{array}
$$

エネルギ吸収効率 $\eta=\frac{Q}{P_{\max } \times \delta_{\max }} \times 100[\%]=\frac{P_{m}}{P_{\max }} \times 100[\%]$

7. 結言

（1）中空形材に孔を貫通させると, 第 1 ピーク荷重が抑えられ, ピーク荷重後は孔なしと同様の荷重の推移を示す.

(2) 中空形材の緩衝器に通す孔はエネルギ吸収量, 緩衝効率の 点からピッチに対して, 孔径が Model-1 0.6 付近が有効 である.Model-2 は 0.8 付近が有効であると考えられる. 文献

(1) 酒井, 岡本: 日本機械学会, 講演論文集No. 060-1, pp4 23-424, 2006. 3.

（2）角田, 岡本, 他 4 名: 機講論, Vol.70, No.600, 1001-1002，(2005-10) 